\title{
Nutritional Status of Rural Obese School going Children (11 - 15 Yrs) in Guntur District
}

\author{
J. Hemamalini ${ }^{1}$, Dr. B. Babitha ${ }^{2}$, B Lalitha Kumari ${ }^{3}$ \\ ${ }^{1}$ Research Scholar, Department of Food \& Nutrition Sciences, ANU, Guntur Dist. A.P, India \\ ${ }^{2}$ Asst Professor, Department of Food \& Nutrition Sciences, ANU, Guntur Dist. A.P, India \\ ${ }^{2}$ Assistant Professor, S\&H Dept. Vignan's University, Vadlamudi, Guntur Dt. A.P. , India
}

\begin{abstract}
The purpose of study is to find the nutritional status of obese school going children aged 11-15 years and comparison is taken between the corporate school children and Government school children in Nambur mandal, Guntur District of Andhra Pradesh. General information, Anthropometry method, and dietary intakes were assessed by using standard methods. Basic variables like height, weight, waist circumference were taken for anthropometry measurements using standard techniques. 24 hour recall method was taken for dietary intake. The prevalence of over nutrition was significantly high in corporate school children than government school children. The incidence of overweight is seen in children of $64.2 \%$ boys and $73 \%$ girls belonging to high income level and studying in corporate school. Where in Government school children, the prevalence is very less i.e. $27.2 \%$ boys and $25.3 \%$ girls were showing obesity.
\end{abstract}

Keywords: Nutritional status, Government and Corporate schools, Anthropometry, Dietary intake, Obesity

\section{Introduction}

Developing countries are undergoing nutrition transition due to increased economic development and market globalization leading to rapid changes in lifestyle and dietary habits. The burden of obesity has increased exponentially, affecting all socio-economical groups of both developed and developing countries, irrespective of age, sex and ethnicity in recent decades. This prompted WHO to describe obesity as an escalating global epidemic.

Anthropometrics can be sensitive indicators of health, growth and development in infants and children. (Aindrila et al., 2014).

Nutritional status during adolescence plays an important role in human lifecycle. The global economic development and urbanization has resulted in great changes in the weight status of adolescents worldwide. A decreasing trend in the prevalence of under-nutrition has been identified in developing countries. On the other hand, an increasing shift towards higher rates of overweight and obesity among adolescents has been reported in developed and developing countries. The National Food Consumption Survey conducted in 2001-2003 showed that the prevalence of thinness, preobesity and obesity among boys aged 15 to 19 years old was $27.6 \%, 5.1 \%$ and $3.6 \%$, respectively. The related figures for girls were $10.5 \%, 9.7 \%$ and $3.9 \%$, respectively. Prevalence of overweight in high school students increased to $11.2 \%$ in 2004. As a result, new cases of children with the metabolic syndrome may appear which in turn is likely to create an enormous economic and public health burden for Iran in the near future (Aazam Doustmohammadian et al., 2013).
In India approximately $19 \%$ of the growing population comprises school-aged children of whom $30 \%$ currently reside in urban India. A significant increase number of these children belong to middle and high socio-economic groups.

The WHO defines obesity as an excess body fat which will have an adverse effect on wellbeing and health. The international obesity task force (IOTE) assets that the occurrence of the obesity epidemic is twofold. The excess intake of food and beverages with high energy load leads to overconsumption of energy and further an environment that restricts one's opportunities for physical activity which results in a universally sedentary state (N. Larrañaga, et al 2007).

To develop effective interventions it is important to better understand the factors that increase risk for overweight and obesity in youth .The American dietetic association (ADA) recently published a detailed evidence analyses on dietary and physical activity (PA) variables that may predispose youth to overweight and obesity (Ruth S.M. Chan \& Jean Woo,2010)

The objective of the present study is to find out the nutritional status of the obese school going children between the age group of 11-15 years

\section{Methodology}

The present work is on assessing nutritional status of obese school going children. The main focus of the present study was to find out the food intake associated with obesity among school going and adolescents boys and girls of 11-15 yrs of age. To achieve the objectives the following parameters were selected. 


\section{International Journal of Science and Research (IJSR) \\ ISSN (Online): 2319-7064 \\ Index Copernicus Value (2013): 6.14 | Impact Factor (2014): 5.611}

Sample selection: For present study, samples were selected from two schools i.e. corporate and government school situated in and around Acharya Nagarjuna University, Guntur (Dt).A.P. These subjects were in selected school going children.

General information: Age, sex, parent education, occupation, type of family, income level, family size, physical activity and life style characteristics were collected by using a prepared questionnaire.

\section{Anthropometric parameters:}

- Height

- Weight

- Waist circumference

Following the recommendations of World Health Organisation

Dietary and nutrient intakes: 24 hours recall method and weighment method were used to collect the 3 days diet i.e. two week days and one week end. Dietary pattern, dietary intakes, nutrition composition were calculated by using NIN nutrient composition tables (ICMR, 2010).

\section{Results and Discussion}

Comparative study of obese children in corporate and government school (11-15) was taken in the present study. Obesity is a growing public health problem in worldwide and its prevalence has increased in all age groups. The study is carried out by selecting the samples from two schools located near the Nagarjuna University, Guntur, AP. Subjects in the age group of 11-15 years were drawn from these two schools. The selected number of subjects were 100 school going boys and girls belong to this group and their nutritional status, dietary habits and other aspects were recorded.

1. General Information of the Subjects: The general information was collected to know all the different aspects that affects the stages of and individual general information was taken which included age (11-15yrs). The general information of the obese school going children in two schools was shown in table 2 .

Age: The data was collected in two schools of both boys and girls of 11-15 age groups. The percentage of the subjects at various ages groups are recorded i.e.11-15 years are (14.8\%), $12-13$ years are $(28.12 \%), 13-14$ years are $(32.02 \%), 14-15$ years are $(11.6 \%)$ and girls $11-15$ years are $(12.4 \%)$.

Family Size: The data was collected in two schools with 4 members of family size was $(42.5 \%)$ less than $(12.6 \%)$ greater than $(46 \%)$ for boys, girls $(47.2 \%)$ greater than 5 members $(12.2 \%)$ less than 4 members $(32.3 \%)$. Comparatively, girl's percentage was higher than boys.

Literacy: Literacy levels of subjects from two schools were considered as seventh, eighth, ninth, tenth $-52.4 \%$ were seventh class, $62 \%$ were eighth class, $45.3 \%$ were ninth class and $36.1 \%$ were tenth class respectively.

Type of Family: Type of family also plays an important role in health of the individuals. The recorded data showed, $13.6 \%$ subjects were in joint family and $86.3 \%$ were in nuclear family.

Income Level: Income level also plays an important role in all the aspects of one's food choice and habits. Data collected from two schools of different sections are devised for boys and girls for boy's low, middle, high income levels are $18.1 \%, 54.2 \%, 27.2 \%$. For girls low, middle, high income levels are $-16.6 \%, 50 \%, 73.4 \%$. Corporate school income levels for boys are $-5.32 \%, 48.9 \%, 64.2 \%$, for girl's income levels are $6.32 \%, 33.3 \%, 25.3 \%$. On an average middle monthly income value is high for both boys and girls.

Diet History: Diet is most important aspect while collecting the data. It is the major aspect where total food habits should be known in the diet history. Here diet histories are divided into two sections - vegetarians $74.2 \%$, non- vegetarians $92.6 \%$. The girl's data of the vegetarian values were $67.5 \%$ and non vegetarians were $72.9 \%$. Comparatively, in two sections the non - vegetarians are high in corporate sector.

Table 1: General information of the obese school going children-boys $\&$ girls (11-15 yrs)

\begin{tabular}{|c|c|c|c|c|}
\hline \multirow{2}{*}{ Age } & \multicolumn{2}{|c|}{ Boys } & \multicolumn{2}{c|}{ Girls } \\
\cline { 2 - 5 } & $\begin{array}{c}\text { GOVT } \\
\text { N-16 }\end{array}$ & $\begin{array}{c}\text { CORP } \\
\text { N-32 }\end{array}$ & $\begin{array}{c}\text { GOVT } \\
\text { N-22 }\end{array}$ & $\begin{array}{c}\text { CORP } \\
\text { N-30 }\end{array}$ \\
\hline $11-12$ & $14.8 \%$ & $17.9 \%$ & $13.32 \%$ & $21.3 \%$ \\
$12-13$ & $28.12 \%$ & $28.5 \%$ & $11.6 \%$ & $13.4 \%$ \\
$13-14$ & $32.02 \%$ & $33.1 \%$ & $16.2 \%$ & $20 \%$ \\
$14-15$ & $11.6 \%$ & $9.31 \%$ & $9.0 \%$ & $12.4 \%$ \\
\hline Family size & & & & \\
$=4$ & $42.5 \%$ & $39.9 \%$ & $41.3 \%$ & $38.2 \%$ \\
$<4$ & $12.6 \%$ & $43.4 \%$ & $9.32 \%$ & $42.3 \%$ \\
$>4$ & $46 \%$ & $18 \%$ & $47.2 \%$ & $20 \%$ \\
\hline Literacy level of the & & & & \\
parents & $91.5 \%$ & $10.4 \%$ & $89.3 \%$ & $11.8 \%$ \\
Mothers: & $8.3 \%$ & $90.6 \%$ & $11.7 \%$ & $90 \%$ \\
Illiterates: & & & & \\
Literates: & $55.3 \%$ & $25.4 \%$ & $45.3 \%$ & $19.3 \%$ \\
Father: & $54.2 \%$ & $87.3 \%$ & $62.6 \%$ & $83.4 \%$ \\
Illiterates: & & & & \\
\hline Type of family & & & & \\
Joint: & $13.6 \%$ & $35.2 \%$ & $28.3 \%$ & $13.3 \%$ \\
Nuclear: & $86.3 \%$ & $68.2 \%$ & $72.1 \%$ & $80.3 \%$ \\
\hline Income level & & & & \\
Low & $18.1 \%$ & $5.32 \%$ & $16.6 \%$ & $6.32 \%$ \\
Middle & $54.5 \%$ & $48.9 \%$ & $50 \%$ & $33.3 \%$ \\
high & $27.2 \%$ & $64.2 \%$ & $73.4 \%$ & $25.3 \%$ \\
\hline Vegetarians & $86.6 \%$ & $13.6 \%$ & $83.3 \%$ & $16.6 \%$ \\
\hline Non-vegetarians & $15.4 \%$ & $81.2 \%$ & $17.4 \%$ & $78.2 \%$ \\
\hline
\end{tabular}

2. Anthropometric Assessment of Obese Boys \& Girls

Taking anthropometric measurements is an important aspect to know individual body composition.

Volume 4 Issue 12, December 2015 


\section{International Journal of Science and Research (IJSR) \\ ISSN (Online): 2319-7064 \\ Index Copernicus Value (2013): 6.14 | Impact Factor (2014): 5.611}

Height: The standard height for the age group of $11-15$ years was $151.1-166.3 \mathrm{~cm}$ for boy's and $150.2-158.8$ for girls. The mean heights are 160,155 and $154 \mathrm{~cm}$ for $11-15$ years of age group which are high comparatively to the standard heights of obese boys and girls.

Weight: Body weight is the most widely used sensitive and simplest reproducible anthropometric measurement used for the evaluation of nutritional status. It reflects more recent nutrient than height does.

Table 2: Mean values of height and weight obese boys (11-15) years

\begin{tabular}{|c|c|c|c|c|c|c|}
\hline & \multicolumn{3}{|c|}{ Height } & \multicolumn{3}{|c|}{ Weight } \\
\hline \multirow[t]{2}{*}{ Age group } & \multicolumn{2}{|c|}{ Mean \pm SD } & \multirow[b]{2}{*}{ Reference standard } & \multicolumn{2}{|c|}{ Mean \pm SD } & \multirow[b]{2}{*}{ Reference standard } \\
\hline & Govt & Corporate & & Govt & Corporate & \\
\hline $11-12$ & $144.5 \pm 7.02$ & $151.1 \pm 5.79$ & 151.1 & $44.70 \pm 6.04$ & $47.29 \pm 8.5$ & 38.0 \\
\hline $12-13$ & $145.8 \pm 6.32$ & $152.2 \pm 5.07$ & 157.0 & $45.87 \pm 5.59$ & $48.62 \pm 8.4$ & 43.3 \\
\hline $13-14$ & $146.7 \pm 7.22$ & $154.1 \pm 4.69$ & 163.0 & $48.04 \pm 5.28$ & $52.83 \pm 7.2$ & 48.0 \\
\hline $14-15$ & $148.7 \pm 6.44$ & $156.0 \pm 3.65$ & 166.3 & $50.35 \pm 3.91$ & $56.94 \pm 6.3$ & 51.5 \\
\hline
\end{tabular}

Table 3: Mean values of height and weight obese girls (11-15) years

\begin{tabular}{|c|c|c|c|c|c|c|}
\hline \multirow{2}{*}{ Age group } & \multicolumn{2}{|c|}{ Mean \pm SD } & \multirow{2}{*}{ Reference Standard } & \multicolumn{2}{|c|}{ Mean \pm SD } & \multirow{2}{*}{ Reference Standard } \\
\cline { 2 - 5 } & Govt & Corporate & & Govt & Corporate & \\
\hline $11-12$ & $145.9 \pm 6.92$ & $151.3 \pm 5.79$ & 150.2 & $45.05 \pm 5.81$ & $47.70 \pm 8.8$ & 39.0 \\
\hline $12-13$ & $145.8 \pm 6.57$ & $152.6 \pm 5.41$ & 153.8 & $46.42 \pm 5.58$ & $50.29 \pm 8.50$ & 43.4 \\
\hline $13-14$ & $145.9 \pm 7.06$ & $153.9 \pm 4.94$ & 157.0 & $47.51 \pm 5.16$ & $53.93 \pm 7.52$ & 47.1 \\
\hline $14-15$ & $147.8 \pm 6.66$ & $155.7 \pm 3.57$ & 158.8 & $48.82 \pm 4.89$ & $57.32 \pm 6.59$ & 49.4 \\
\hline
\end{tabular}

Table 4: $\mathbf{t}$-values for height and weight between corporate and government schools

\begin{tabular}{|c|c|c|}
\hline \multicolumn{3}{|c|}{ Boys } \\
\hline \multirow{2}{*}{ Age } & Height & Weight \\
\cline { 2 - 3 } & \multicolumn{2}{|c|}{ t- value } \\
\hline $11-12$ & 0.002 & 0.2909 \\
\hline $12-13$ & 0.00013 & 1.147 \\
\hline $13-14$ & 0.00023 & 1.432 \\
\hline $14-15$ & 0.0014 & 6.913 \\
\hline \multicolumn{3}{|c|}{ Girls } \\
\hline $11-12$ & 0.0216 & 1.554 \\
\hline $12-13$ & 0.0033 & 0.0043 \\
\hline $13-14$ & 0.01652 & 0.003 \\
\hline $14-15$ & 0.0076 & 1.426 \\
\hline
\end{tabular}

$\mathrm{T}$ test values for two schools were shown in table 5. From the table it was clear that the weight of subjects between $11-15$ years was highly significant at 1 percent level between the schools. For height less significant i.e. 5 percent level between the schools.

\section{The third section related to food and nutrient intake of school going children:}

Dietary history can be an essential component to understand a person's dietary habit, choice of food and eating pattern. Sometimes this can be useful in assessing an individual's care of obesity to an event.

Dietary history: Boy's data taken in a day plays an important role in determining a person's nutritional status. Both boys and girls depended more on fast foods and less on meals and thus mostly miss the normal meal pattern.

Table 5: Meal pattern of subjects

\begin{tabular}{|c|c|c|c|}
\hline $\begin{array}{l}\text { S. } \\
\text { No }\end{array}$ & $\begin{array}{c}\text { Meal } \\
\text { Schedule }\end{array}$ & Time & Item for different courses \\
\hline 1. & $\begin{array}{c}\text { Early } \\
\text { Morning }\end{array}$ & $7.00 \mathrm{AM}$ & $\begin{array}{l}\text { Milk/flavoured } \\
\text { milk/fruits/water }\end{array}$ \\
\hline 2. & Breakfast & $\begin{array}{c}8.00-8.30 \\
\text { AM }\end{array}$ & $\begin{array}{l}\text { Idli/dosa/upma/magi/chap } \\
\text { athi/puri/lemon rice with } \\
\text { chutnies/vegetables } \\
\text { curry/sambar/kichidi }\end{array}$ \\
\hline 3. & $\begin{array}{c}\text { Mid } \\
\text { morning }\end{array}$ & $11.00 \mathrm{AM}$ & $\begin{array}{c}\text { Sprouts/fruits/coconut } \\
\text { water/fruits/soft } \\
\text { drinks/fast foods(Bakery) }\end{array}$ \\
\hline 4. & Lunch & $\begin{array}{l}12.30- \\
1.30 \mathrm{PM}\end{array}$ & $\begin{array}{c}\text { Rice }+ \text { vegetable } \\
\text { curry/dal/non-vegetarian } \\
\text { curry/leafy } \\
\text { vegetable/sambar/curd/but } \\
\text { ter milk/Chapathi/fruits }\end{array}$ \\
\hline 5. & $\begin{array}{l}\text { Evening } \\
\text { Snacks }\end{array}$ & $\begin{array}{l}4.30-5.30 \\
\text { PM }\end{array}$ & $\begin{array}{c}\text { Chat/Panipuri/biscuits/pak } \\
\text { oda/milk/fruits/veg and } \\
\text { non- veg puffs }\end{array}$ \\
\hline 6. & Dinner & $\begin{array}{c}7.30-8.30 \\
\text { PM }\end{array}$ & $\begin{array}{c}\text { Rice/pulka/chapathi/dal/ve } \\
\text { getable/non vegetarian } \\
\text { curry/rasam/sambar/curd/b } \\
\text { uttermilk }\end{array}$ \\
\hline 7. & Bed time & $10.00 \mathrm{PM}$ & Milk/fruits \\
\hline
\end{tabular}

Snacks in between meals often can lead to an imbalanced diet, which lead to the overweight depending upon quantity of foods. Data collected from two schools showed $98 \%$ of boys and girls are interested in about taking the snake items. Carbonated beverages provide empty calories. Even then 100

\section{Volume 4 Issue 12, December 2015}




\section{International Journal of Science and Research (IJSR) \\ ISSN (Online): 2319-7064 \\ Index Copernicus Value (2013): 6.14 | Impact Factor (2014): 5.611}

percent of boys and girls preferred drinks and beverages. Dessert or fried foods are considered as high calories food. Hence, they were not taken high amounts balanced diet than empty calorie foods. They have taken about alternative days. Physical activity is an important aspect in order to maintain fitness. The boys and girls physical activity is less when compared to girls. $83.2 \%$ of girls and $85 \%$ of boys were maintaining their fitness through physical activity.

Table 6 shows the three meal pattern i.e. breakfast, lunch and dinner. In the early morning, the school going children generally miss breakfast. For breakfast chapatti/ puri / mysore bajji etc. were taken with any curry in the dietary pattern, taking any bakery foods-pizzas/cakes/drinks etc. and the lunch consists of Biryani / any non-vegetable curry. Evening also they preferred fast foods. Dinner and breakfast items were taken along with milk/ juices during bedtime.

\section{Dietary and Nutritional Intakes}

Data on dietary consumption of subjects were collected using $24 \mathrm{hrs}$ recall and weightment method for 3 days. Standard big and small stainless katories or set of tea and table spoons used in nutritional laboratory were distributed to the subjects to collect quantitative food intakes. The subjects were requested to report about their dietary intakes for the 3 days.

Table 6: Nutrients intakes of obese school going children boys and girls

\begin{tabular}{|c|c|c|c|c|c|c|}
\hline \multirow[b]{3}{*}{ Nutrients } & \multicolumn{3}{|c|}{ Girls } & \multicolumn{3}{|c|}{ Boys } \\
\hline & \multicolumn{2}{|c|}{ Mean \pm SD } & \multirow[b]{2}{*}{ RDA } & \multicolumn{2}{|c|}{ Mean \pm SD } & RDA \\
\hline & Govt & Corporate & & Govt & Corporate & \\
\hline Energy & $2038.2 \pm 340.2$ & $2101.0 \pm 288.8$ & 2450 & $2055.4 \pm 319.5$ & $2120 \pm 276.5$ & 2060 \\
\hline Protein & $60.6 \pm 3.34$ & $55.05 \pm 10.45$ & 70 & $55.2 \pm 6.18$ & $55.5 \pm 10.45$ & 65 \\
\hline Fat & $27.7 \pm 3.43$ & $27.91 \pm 7.9$ & 22 & $25.9 \pm 6.53$ & $28.2 \pm 7.8$ & 22 \\
\hline Iron & $14.4 \pm 2.62$ & $17.2 \pm 7.40$ & 41 & $22.08 \pm 8.92$ & $17.48 \pm 7.44$ & 28 \\
\hline
\end{tabular}

Calories Intake: The mean energy taken for both the schools boys was 2038.2 and $2101.0 \mathrm{Kcal}$ and for girls was 2055.4 and $2120.2 \mathrm{kcal}$ respectively. RDA for energy was $2450 \mathrm{kcal}$ for boys and girls $2060 \mathrm{kcal}$. So the energy intake was less than the RDA.

Protein Intake: The boys mean protein intake of 11- 15 years 60.6 and 55.05 RDA of protein was 70 . The girls mean protein intake of 11-15 years 55.2 and 55.5. RDA of protein was 65 . When compared with the RDA protein intake of boys was 10 percent deficit.

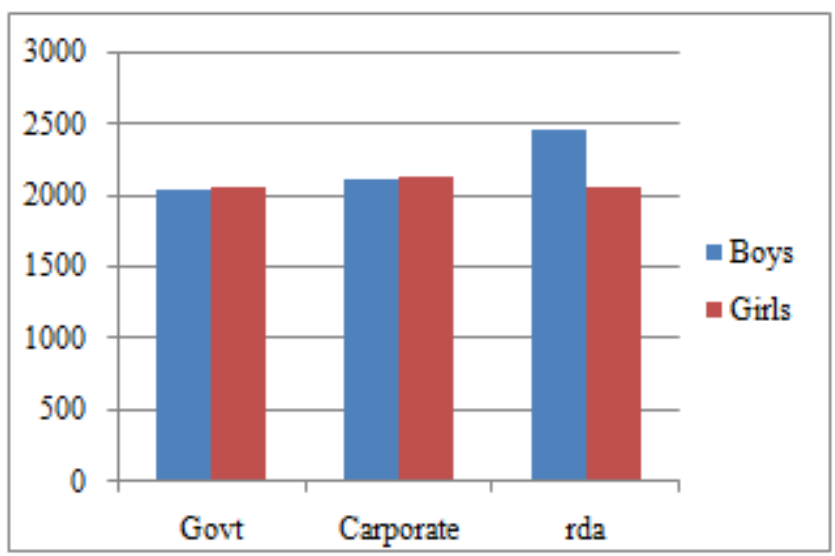

Figure 1: Mean Intake of Calories

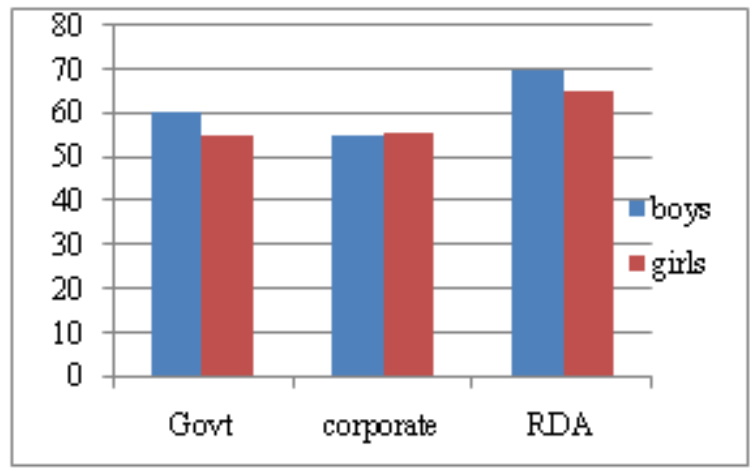

Figure 2: Mean Intake of Protein

Fat Intake: Boys mean intake of fat was 27.7 and $27.9 \mathrm{~g}$, RDA was $22 \mathrm{~g}$. For girls mean fat intake was 25.9 and 28.2, RDA was 22. Fat intake was higher when compared with RDA for both boys and girls.

Iron Intake: The boys mean intake of iron value was 14.4 and 17.2, RDA was 41. For girls mean intake iron value was 22.08 and 17.48 , RDA was 28 . 


\section{International Journal of Science and Research (IJSR) \\ ISSN (Online): 2319-7064}

Index Copernicus Value (2013): 6.14 | Impact Factor (2014): 5.611

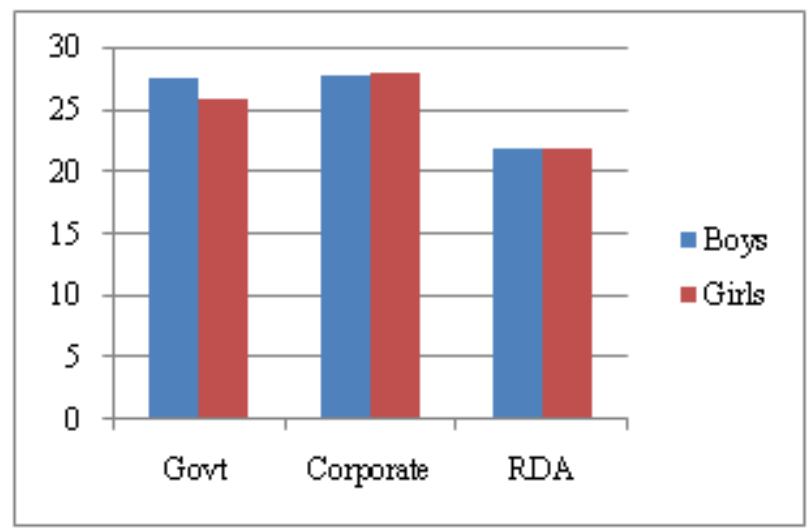

Figure 3: Mean Intake of Fat

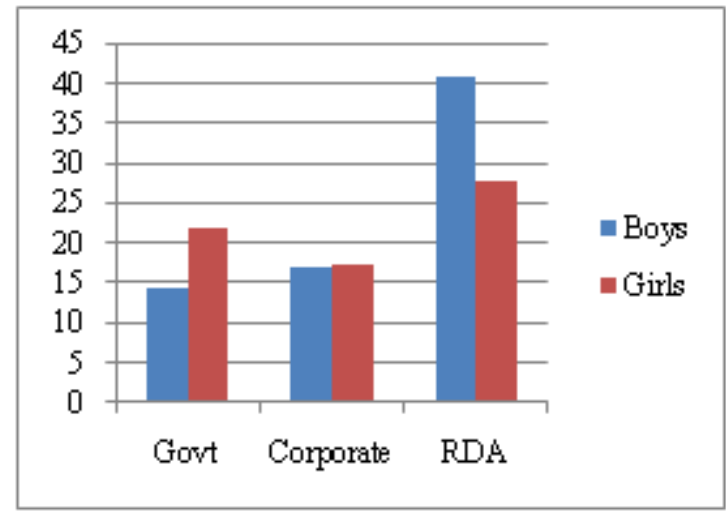

Figure 4: Mean Intake of Iron

To conclude about the nutrient intake of boys and girls were calorie and fat intake was significantly showed difference than the RDA. Protein intake was average than RDA. The mean value of iron was lower than the RDA.

The present results on agreement with Minati Singh, 2014 reported that the habit of eating fast food items between meals is common among teenagers. Cookies, fruit, milk, soft drinks and candy are the five most frequently consumed food.

\section{Summary and Conclusion}

School going children are pinpointed as a period of great storm and stress as well as immense physical, mental and emotional potential. Adolescence between $10-18$ years of age is very dynamic period of human life and the nutritional requirement in terms of body cell mass during adolescence indicates special significance of the nutritional pattern in this period. Life styles of the adolescents influence their intake of nutrients and affect their food habits as well as their physiological requirements for nutrients.

Obesity is becoming a worldwide problem affecting all levels of the society and is being described as a global epidemic. The epidemic of school going children showed obesity which is well documented and presented a major health issue that gave a new path in the medical field to find a new solution to overcome the present burning problem i.e. Obesity. To develop effective interventions, it is important to understand the nutrient intake patterns to overcome the increased risk of overweight which in turn leads to obesity in youth.

\section{References}

[1] Aindrila Das, Sreejit Ghosh, Samir Kumar Ghosh and Rajib Biswas. Evaluation of Physical Growth Status of Boys from Low Income Families of Slums of Kolkata", J Hum Ecol, 45(1): 69-75 (2014).

[2] Aazam Doustmohammadian, Seyed Ali Keshavarz, Sorayya Doustmohammadian , Mitra Abtahi, Minoo Shahani." Nutritional status and dietary intake among adolescent girls". Journal of Paramedical Sc iences (JPS) Vol 4 (Winter 2013) Supplement ISSN 2008-4978.

[3] N. Larrañaga, P. Amiano, J. J. Arrizabalaga, J. Bidaurrazaga and E. Gorostiza." Prevalence of obesity in 4-18-year-old population in the Basque Country, Spain". Obesity Reviews.Volume 8,Issue 4,pages 281-287,july 2007.

[4] Ruth S.M. Chan * and Jean Woo." Prevention of Overweight and Obesity: How Effective is the Current Public Health Approach". ISSN 1660-4601. Int. J. Environ. Res. Public Health 2010, 7, 765-783; doi:10.3390/ijerph7030765.

[5] Wendy E. Barrington; Rachel M. Ceballos; Sonia K. Bishop, BS; Bonnie A. McGregor; Shirley A.A. Beresford." Perceived Stress, Behavior, and Body Mass Index Among Adults Participating in a Worksite Obesity Prevention Program, Seattle, 2005-2007". Centers for disease and control prevention. Volume 9 - October 04, 2012.

[6] Minati Singh."Mood, Food and Obesity".Frontiers in Psychology. September 2014, volume5, article1.

[7] World Health Organisation, Measuring change in nutritional status. World Health Organisation,Geneva, 1983. 